\title{
PERAN EKSTRAKURIKULER DALAM MENINGKATKAN KARAKTER SANTRI PONDOK PESANTREN
}

\author{
Nur Hidayat \& Azzah Zayyinah \\ (Dosen PGMI FITK UIN Sunan Kalijaga Yogyakarta)
}

\begin{abstract}
The results showed: (1) existing extracurricular at Islamic boarding school daughter Nurul Ummah (PPNU-Pi) is the Rural Development Team (TBD) engaged in propaganda, hadrob (Azkiya'), calligraphy, and extracurricular writing (recitation). The implementation of all extracurricular have been running well, because it was done as the existing plan. (2) The Fourth extracurricular instrumental in increasing the value of the character-Pi PPNU students namely: religious, honest, tolerance, discipline, hard work, creative, independent, democratic, curiosity, reward achievement, communicative, love peace, likes to read, care about the environment, social care, and responsibility. (3) Factors supporting the implementation of extracurricular is motivation, a sense of sincerity, cohesiveness owned extracurricular students who follow and support provided by outside parties both administrators, caregivers and alumni, as well as the available infrastructure. While obstacle factors are insufficient infrastructure, the quality of buman resources (HR) and declining vigor in performing activities less stable.

Keywords: character, extracurricular
\end{abstract}

\section{A. Pendahuluan}

Problem kemerosotan moral akhir-akhir ini menjangkit pada sebagian generasi muda. Gejala kemerosotan moral antara lain diindikasikan dengan merebaknya kasus penyalahgunaan narkoba, pergaulan bebas, kriminalitas dan aneka perilaku kurang terpuji lainnya. Tidak sedikit pemuda yang gagal menampilkan akhlak terpuji sesuai harapan orang tua. Kesopanan, sifat-sifat ramah, tenggang rasa, rendah hati, suka menolong, solidaritas sosial dan sebagainya yang merupakan jati diri bangsa yang berabad-abad seolah-olah kurang begitu melekat secara kuat dalam pribadi mereka. ${ }^{1}$ Selain itu, komunikasi secara verbal pada anak semakin berkurang dan cenderung egois dan egosentris. Mereka menginginkan hasil secara instan tanpa mau berusaha maksimal terlebih dahulu. Pada intinya kemerosotan nilai karakter yang terjadi sehingga meresahkan banyak pihak.

${ }^{1}$ Mawardi Lubis, Evaluasi Pendidikan Nilai (Perkembangan Moral Keagamaan PTAIN), Yogyakarta: Pustaka Pelajar, 2009, hlm. v.

LITERASI, Volume. V, No. 1 Juni 2014 
Oleh karena itu perlu adanya pengendali yang dapat menanggulangi masalah ini. Pembentukan watak melalui penanaman nilai bagi generasi muda akan lebih efektif jika mereka berada dan berinteraksi dalam lingkungan non-formal. Lingkungan non formal yang dimaksud penulis adalah lingkungan pondok pesantren. Adapun yang berada di dalamnya disebut dengan santri. Lingkungan ini menurut penulis merupakan lingkungan yang cocok sebagai wahana santri dalam mengembangkan nilai-nilai karakter.

Dalam hal ini, pondok pesantren adalah salah satu lembaga pendidikan non formal yang sangat berperan besar sekali dalam menanggulangi dan meminimalisir adanya kemerosotan tersebut. Lembaga ini adalah lembaga pendidikan Islam tertua di Indonesia yang telah mampu mencetak kader-kader ulama dan telah berjasa mencerdaskan masyarakat Indonesia. Selain itu juga menjadi pusat kegiatan pendidikan yang telah berhasil menanamkan semangat kewiraswastaan, kemandirian, dan patriotik. $^{2}$

Pondok pesantren memiliki ciri umum dengan adanya Kyai/Pengasuh, Santri, dan pondokan/asrama, dan pengkajian ilmu. ${ }^{3}$ Pengkajian ilmu yang terdapat dalam kurikulum yang diterapkan antara pesantren satu dengan yang lain tentu berbeda. Dalam menetapkan kurikulum, pengasuh atau pengelola pondok pesantren mempertimbangkan situasi dan kondisi tempat, ragam usia, dan kebutuhan santri.

Realitas menunjukkan saat ini lembaga pesantren telah berkembang secara bervariasi dilihat dari segi kurikulumnya. Dari yang awalnya hanya kajian kitab kuning dan sorogan al-Quran hingga saat ini pesantren penuh dengan kegiatan keagamaan maupun kegiatan yang mengasah kecakapan hidup atau yang sering disebut dengan kegiatan ekstrakurikuler pondok pesantren. ${ }^{4}$

Kegiatan ekstrakurikuler adalah kegiatan yang dilakukan di luar jam pelajaran tatap muka yang dilaksanakan di sekolah atau luar sekolah untuk memperkaya dan memperluas wawasan pengetahuan dan kemampuan yang telah dipelajari dari berbagai mata pelajaran dalam

${ }^{2}$ Abdul Rachman Shaleh, Pendidikan Agama dan Keagamaan. (Jakarta: PT. Gemawindu Pancaperkasa. 2000), hlm. 224.

${ }^{3}$ Mastuki dkk, Manajemen Pondok Pesantren. (Jakarta: Diva Pustaka. 2005), hlm. 3.

${ }^{4}$ Ibid., hlm. 74. 
kurikulum. $^{5}$ Dengan demikian, kegatan ekstrakurikuler di pondok pesantren adalah kegiatan belajar yang dilakukan oleh santri di luar jam mengaji al-Quran dan kitab.

Kegiatan ekstrakurikuler dalam pondok pesantren memegang peran yang penting karena menjadi wahana dalam mengembangkan nilainilai karakter yang secara teori telah mereka dapatkan di bangku sekolah formal maupun kegiatan belajar mengajar yang ada di dalam pondok pesantren. Dalam kegiatan ekstrakurikuler inilah para santri dapat mengasah dan mengaplikasikan nilai-nilai karakter dengan lebih kompleks jika dibandingkan ketika mereka berada di bangku kelas belajar.

Tujuan penting kegiatan ekstrakurikuler ini adalah sebagai wahana pengembangan karakter santri. Karena dalam aplikasinya, semua kegiatan ekstrakurikuler yang ada membutuhkan komunikasi satu dengan yang lainnya. Mereka akan belajar bagaimana cara bersosialisasi, bermasyarkat, bersikap dan bertindak. Semuanya mereka pelajari termasuk bagaimana cara penyelenggara ekstra mengatur anggotanya, bagaimana cara interaksi antar anggota dan bagaimana cara semua anggota ekstra berkomitmen terhadap tugas dan kewajibannya. Fenomena inilah yang menjadi latar belakang penulis untuk mengadakan penelitian tentang peran kegiatan ekstrakurikuler dalam meningkatkan karakter santri di Pondok Pesantren Nurul Ummah Putri Kotagede Yogyakarta.

Di Pondok Pesantren Nurul Ummah Putri (selanjutnya disingkat PPNU-Pi) yang penulis teliti, memiliki banyak bidang ekstrakurikuler. Di antaranya adalah kegiatan ekstrakurikuler Tim Bina Desa (TBD) yang bergerak dalam dunia dakwah, Karya Tulis (Tilawah), Seni Hadrah (Azkiya'), dan Seni Kaligrafi. Melalui kegiatan ekstrakurikuler itulah diharapkan santri dapat mengikuti salah satu atau beberapa bidang sesuai dengan minat dan bakatnya dengan tujuan untuk mengasah nilai-nilai karakter yang dapat menghantarkan mereka menjadi manusia-manusia berkarakter.

\section{B. Metode Penelitian}

Jenis penelitian yang akan digunakan penulis dalam penelitian ini adalah jenis penelitian lapangan berupa penelitian kualitatif yang bersifat hlm. 271.

5Suryosubroto, Proses Belajar Mengajar di Sekolah, (Jakarta: PT Rineka Cipta, 2002), 
deskriptif non statistik. ${ }^{6}$ Penelitian sosial menggunakan format deskriptif kualitatif bertujuan untuk menggambarkan, meringkas berbagai kondisi, berbagai situasi, dan berbagai fenomena realitas sosial yang ada di masyarakat yang menjadi objek penelitian, dan berupaya menarik realitas itu ke permukaan sebagai suatu ciri, karakter, sifat, model, tanda, atau gambaran tentang kondisi, situasi, ataupun fenomena tertentu.

1. Subyek Penelitian, berikut sumber data peneliti:

a.Ketua dan anggota Ekstrakurikuler Tim Bina Desa (TBD)

b. Anggota Ekstrakurikuler Karya tulis (Tilawah) saja karena ekstra ini diketuai oleh santri putra.

c.Ketua dan anggota Ekstrakurikuler Hadrah (Azkiya')

d. Ketua dan anggota Ekstrakurikuler Kaligrafi

e.Para alumni PPNU-Pi yang pernah berkecimpung dalam Ekstrakurikuler

2. Metode Pengumpulan Data

a.Metode Observasi

Metode observasi adalah suatu cara pengumpulan data dengan menggunakan indra, terutama indra penglihatan dan pendengaran. ${ }^{7}$ Observasi yang dilakukan penulis adalah observasi non partisipan, karena penulis hanya mengamati kegiatan ekstrakurikuler saja tanpa terjun langsung dalam anggota kelompok.

b. Metode Interview (wawancara)

Interview atau wawancara adalah sebuah dialog yang dilakukan oleh pewawancara untuk memperoleh informasi dari terwawancara. ${ }^{8}$ Dalam melakukan wawancara, penulis mengambil sampel antara lain:

a. Ketua dan beberapa anggota Ekstrakurikuler TBD

b. Anggota Ekstrakurikuler Karya tulis (Tilawah)

c. Ketua dan beberapa anggota Ekstrakurikuler Hadrah (Azkiya')

d. Ketua dan beberapa anggota Ekstrakurikuler Kaligrafi

${ }^{6}$ Robert Bogdan, Pengantar Metode Penelitian Kualitatif, (Surabaya: Usaha Nasional, 1992), hlm. 21-22.

${ }^{7}$ Lexu J. Moloeng, Metodologi Penelitian Kualitatif, (Bandung: Remaja Rosdakarya, 1993), hlm. 127.

${ }^{8}$ Suharsimi Arikunto, Prosedur Penulisan: Suatu Pendekaan Praktek, (Jakarta: Rineka Cipta Edisi Revisi IV, 1998), hlm. 155. 
e. Beberapa alumni PPNU-Pi yang pernah berkecimpung dalam Ekstrakurikuler

c.Dokumentasi

Metode dokumentasi adalah salah satu metode pengumpulan data yang digunakan dalam metodologi pengumpulan data yang digunakan dalam penulisan sosial. Oleh karena sebenarnya sejumlah besar fakta dan data sosial tersimpan dalam bahan yang berbentuk dokumentasi. ${ }^{9}$

3. Teknik Analisis Data

Analisis data merupakan suatu penguraian yang berisi interpretasi, penilaian, komentar, tanggapan dari penulis. Untuk mengolahnya, penulis menggunakan teknik analisis deskriptif kualitatif, yakni setelah pengumpulan data selesai, penulis mencoba memaparkan sedetail mungkin dan dianalisis kemudian diinterpretasikan dengan jelas untuk menjawab permasalahan yang ada.

\section{Hasil Penelitian Dan Pembahasan}

Ekstrakurikuler adalah kegiatan di luar jam belajar biasa yang bertujuan agar peserta didik dapat memperkaya dan memperluas wawasan pengetahuan dan kemampuan siswa. ${ }^{10}$ Dengan demikian yang dimaksud dengan ekstrakurikuler adalah serangkaian macam kegiatan pengembangan bakat minat yang dilakukan di luar jam tatap muka biasa guna menunjang realisasi kurikulum agar dapat memperluas wawasan, pengetahuan, keahlian, dan kemampuan peserta didik dalam menghayati apa yang telah dipelajari dalam kegiatan intrakurikuler. Hal yang tidak kalah pentingnya adalah ekstrakurikuler sebagai upaya dalam pembinaan kepribadian atau pembinaan karakter.

Secara etimologis, kata karakter (inggris: character) berasal dari bahasa Yunani (Greek), yaitu eharassein yang berarti "to engrave". Kata "to engrave" itu sendiri dapat diterjemahkan menjadi mengukir, melukis, memahatkan, atau menggoreskan. ${ }^{11}$

Karakter menurut Kamus Besar bahasa Indonesia (KBBI) adalah sifat-sifat kejiwaan, akhlak atau budi pekerti yang membedakan seseorang

${ }^{9} I b i d .$, hlm. 121. hlm. 271

${ }^{10}$ Suryosubroto, Proses Belajar Mengajar di Sekolah, (Jakarta: PT Rineka Cipta, 2002),

${ }^{11}$ John Echols dan Hassan Shadily. Kamus Inggris Indonesia: An Engglish-Indonesian Dictionary, (Jakarta: PT Gramedia, 1995), hlm. 214.

LITERASI, Volume. V, No. 1 Juni 2014 
dari yang lain. ${ }^{12}$ Menurut Erich Froom, seorang filosof hebat yang dikutip oleh Moh. Yamin, berpendapat bahwa karakter adalah alasan-alasan, motivasi yang disadari atupun tidak, seseorang melakukan tindakan-tindakan tertentu dengan sifat-sifat karakter. Hakikat karakter harus dicari dalam corak hubungan seseorang dengan lingkungannya, benda maupun manusia baik produktif maupun tidak. ${ }^{13}$

Berikut ini dikemukakan 18 nilai karakter versi Kemendiknas antara lain ${ }^{14}$ : Religius, Jujur, Toleransi, Disiplin, Kerja keras, Kreatif, Mandiri, Demokratis, Rasa ingin tahu, Semangat kebangsaan atau Nasionalisme, Cinta tanah air, Menghargai prestasi, Komunikatif senang bersahabat, Cinta damai, Gemar membaca, Peduli lingkungan, Peduli sosial, dan Tanggung jawab.

Nilai karakter seseorang dengan orang lain berbeda-beda. Tergantung bagaimana seseorang itu mengolah dan memelihara karakter dalam dirinya. Sehingga nilai karakter seseoarang senantiasa meningkat dan berkembang dengan baik. Salah satu cara meningkatkannya adalah melakukan kegiatan positif seperti ekstrakurikuler yang ada di PPNU-Pi.

Ekstrakurikuler ini berperan dalam meningkatkan karakter santri PPNU-Pi. Melalui kegiatan-kegiatan yang dilakukan baik bersifat harian, mingguan maupun tahunan. Semua kegiatan itu mengandung banyak nilai karakter, sehingga santri yang mengikuti ekstrakurikuler akan memiliki karakter yang berbeda dengan santri lain. Mereka menjadi lebih dewasa, pemberani, dan kreatif. Berikut ulasan peran ekstrkurikuler dalam meningkatkan nilai karakter santri PPNU-Pi:

Berikut adalah bidang-bidang ektakurikuler dalam rangka meningkatkan karakter santri PPNU-Pi :

1. Ekstrakurikuler Tim Bina Desa (TBD)

Tim Bina Desa (TBD) adalah lembaga yang dimiliki santri putri Nurul Ummah untuk mendakwahkan syariat Islam. Pelaksanaan TBD adalah setiap hari Ahad pagi pukul 10.00-12.00 WIB. yang berlokasi di Nglipar, Gunungkidul, Yogyakarta. Jarak tempuh antara PPNU-Pi dengan lokasi kurang lebih membutuhkan waktu satu jam. Materi yang

${ }^{12}$ Tim Penyusun Kamus Pusat dan Pengembangan Bahasa, Kamus Besar Bahasa Indonesia, (Jakarta: Balai Pustaka, 2005), hlm. 389. I, hlm. 22.

${ }^{13}$ Moh Yamin, Menggugat Pendidikan Indonesia, (Yogyakarta: Ar-Ruzz Media, 2009) cet 23.

${ }^{14}$ Kemendiknas, Pengembangan Karakter dan Budaya Bangsa (Jakarta:Puskur, 2010), hlm.

72

LITERASI, Volume. V, No. 1 Juni 2014 
disampaikan terkait pelajaran fiqh, sejarah kebudayaan Islam, akblaq, aqidah, Bahasa Arab,al-Quran hadist.

Selain kegiatan setiap hari Ahad, ada satu agenda besar yang dilakukan setiap tahun sekali yaitu Festival Anak Soleh (FAS). Aneka perlombaannya meliputi Pemilihan Da'i Cilik (Pildacil), Musabaqoh Tartil Quran (MTQ), bacaan salat, hafalan surat-surat pendek, adzan dan iqo $>$ mah. Peserta yang mengikuti lomba ini adalah delegasi dari seluruh TPA yang ada di Kabupaten Gunungkidul.

2. Ekstrakurikuler Seni Hadrah (Azkiya)

Azkiya' lahir pada tahun 2008 yang diketuai oleh Saudari Hani Riana. Anggota Azkiya' berjumlah 12 orang yang terdiri dari santri pelajar dan mahasiswa. Karena pada saat itu di MTs dan MA belum ada ekstrakurikuler hadrah. ${ }^{15}$ Adapun sekarang, anggota Azkiya' khusus untuk santri minimal usia lulus MA/SMA beranggotakan sebanyak 15 orang.

Grup Azkiya' melakukan latihan sekali dalam seminggu yaitu pada hari Sabtu atau Ahad sekitar pukul 10.00-1200 WIB. Pelatih hadrah pertama adalah bapak Khoiru Man, alumni yang dulu juga termasuk dalam grup hadrah Nurul Mustofa di PPNU-Pa. Karena kesibukan beliau akhirnya pelatih Azkiya' sementara ini belum ada, hanya saja ada beberapa anggota Azkiya' sedikit bisa sehingga mereka saling belajar mengajari. ${ }^{16}$

3. Ekstrakurikuler Seni Kaligrafi

Kaligrafi adalah seni yang membutuhkan kesabaran tinggi dan kemauan kuat. Ekstrakurikuler ini mulai ada sejak Bu Khusnul mengikuti lomba kaligrafi tingkat Nasional pada tahun 2001. Ibu Nyai Barokah sebagai pengasuh mengetahui hal itu, beliau pun memberikan amanah kepada bu Khusnul untuk mengajarkan ilmu kaligrafi kepada santri-santri yang lain. Adapun jenis tulisan/khat yang dipelajari adalah khat naskhi, sulus, kufi, riq'ah. Ekstra ini dilakukan pada hari Jumat setelah jamaah Asar yang bertempat di mushala Darussalam". ${ }^{17}$

4. Ekstrakurikuler Karya tulis (Tilawah)

\footnotetext{
${ }^{15}$ Wawancara dengan Ibu Hani Riana, alumni PPNU-Pi yang dulu aktif dalam Azkiya'. Pada tanggal 23 April 2013.

16 Wawancara dengan saudari Marfu'atus Solehah, ketua Azkiya'. Pada tanggal 21 Mei 2013. Pukul 09.00 WIB.

17 Wawancara dengan Ibu Khusnul Khotimah, Pelatih ekstrakurikuler kaligrafi pertama. Pada tanggal 23 April 2013.
} 
Ekstrakurikuler tilawah adalah ekstra yang bergelut dalam bidang karya tulis baik opini, essay, puisi, pantun, dan cerpen. Adapun anggota Tilawah terdiri santri putra dan putri Mahasiswa dan Pelajar tingkat Mts/SMP dan MA/SMA yang berjumlah 18 santri putri. Ekstrakurikuler ini memiliki agenda dianaranya adalah menerbitkan Korma (Koran Nurul Ummah) satu minggu dua kali, menerbitkan majalah satu semester/enam bulan satu kali. Tetapi pada kenyataannya, majalah ini hanya dapat terbit satu kali dalam setahun, mengadakan muqaddaman (membaca al-Quran satu kali khataman dalam satu majlis). Rapat evaluasi pada setiap bulan . Berikut diungkapkan nilai-nilai karakter yang muncul pada setiap ekstrakurikuler:

1. Tim Bina Desa (TBD)

Nilai religius, jujur, toleransi, disiplin, kerja keras, kreatif, mandiri, demokratis, rasa ingin tahu, menghargai prestasi, komunikatif, cinta damai, gemar membaca, peduli lingkungan, peduli sosial, dan tanggung jawab.

2. Ekstrakurikuler Azkiya'

Nilai religius, toleransi, disiplin, kerja keras, kreatif, mandiri, demokratis, rasa ingin tahu, komunikatif, cinta damai, dan tanggung jawab.

3. Ekstrakurikuler Kaligrafi

Nilai religius, toleransi, disiplin, kerja keras, kreatif, mandiri, demokratis, rasa ingin tahu, komunikatif, cinta damai, gemar membaca, dan tanggung jawab.

4. Ekstrakurikuler Tulis Menulis (Tilawah)

Nilai religius, jujur, toleransi, disiplin, kerja keras, kreatif, mandiri, demokratis, rasa ingin tahu, menghargai prestasi, komunikatif, cinta damai, gemar membaca, peduli lingkungan, peduli sosial, dan tanggung jawab.

Berikut adalah Faktor Pendukung dan Penghambat Ekstrakurikuler dalam Meningkatkan Karater Santri PPNU-Pi:

1. Faktor Pendukung

Faktor pendukung yang menjadikan ekstrakurikuler ini dapat berperan dalam meningkatkan karakter santri di antaranya adalah semangat yang dimiliki anggota TBD untuk menegakkan kalimat Allah, keikhlasan yang mendasari hati anggota TBD untuk berdakwah, dan adanya dukungan dari berbagai pihak. Pendukung inilah yang menguatkan anggota TBD tetap mengemban amanah mulia, 
menularkan ilmu kepada orang lain, dan berbagi pengalaman dengan sesama.

Sedangkan faktor pendukung ekstrakurikuler Aqkiya' adalah dengan adanya berbagai moment menjadikan Azkiya' selalu latihan, kekompakan yang dimiliki anggota Azkiya', rasa tanggung jawab untuk melestarikan khazanah Islam. Hal ini akan menciptakan rasa semangat yang membara bagi mereka untuk latihan dan mempersembahkan lagu-lagu salawat. Eksistensi latihan menunjukkan berlakunya peran ekstrakurikuler dalam meningkatkan karakter santri PPNU-Pi/anggota Azkiya'.

Berbeda lagi dengan faktor pendukung ekstrakurikuler kaligrafi. Faktor itu meliputi adanya motivasi santri dalam mengikuti ekstra, adanya perlombaan yang diselenggarakan oleh Kementerian Agama baik tingkat kota, propinsi, maupun Nasional yang menjadikan semangat mereka untuk aktif mengikuti ekstra dan latihan. Selain itu, adanya sarana dan prasarana yang tersedia juga mempengaruhi semangat mereka. Adanya dukungan dari berbagai pihak, seperti orang tua, teman, pengurus PPNU-Pi dan para Ustazah, juga merupakan pendukung dari terselenggaranya ekstra ini.

Adapun faktor pendukung yang ada pada ekstra tilawah adalah solidnya kru tilawah dalam ekstrakurikuler ini walaupun terkadang vakum, tetapi ketika diajak bergerak langsung bergegas. Adanya notebook untuk mengolah tulisan demi kelancaran kinerja, menjadi faktor penting dalam ekstra ini. Selain itu, dukungan dari berbagai pihak pengurus PPNU Putra dan Putri serta dari para alumni yang masih peduli terhadap tilawah, juga menjadi cambuk semangat mereka.

Dari sini dapat diringkas bahwa faktor pendukung pelaksanaan ekstrakurikuler adalah adanya semangat/motivasi, rasa ikhlas, kekompakan yang dimiliki santri yang mengikuti ekstrakurikuler dan dukungan yang diberikan oleh pihak luar baik pengurus, pengasuh maupun para alumni, serta tersedianya sarana dan prasarana yang ada.

2. Faktor Penghambat

Ada beberapa faktor penghambat dalam ekstrakurikuler TBD berakibat pada kurang maksimalnya peran ekstrakurikuler dalam meningkatkan karakter santri PPNU-Pi/anggota TBD. Faktor tersebut di antaranya adalah kurikulum pengajaran belum terlalu jelas, sehingga materi yang disampaikan kurang sistematis. Walaupun realitanya materi yang disampaikan sudah mencakup semua mata pelajaran Agama Islam. Kurangnya buku Iqro' dan buku-buku 
pendukung lainnya seperti buku cerita, kisah nabi-nabi, juga menjadi penghambat terselenggaranya TBD. Akibatnya jam ngaji lama karena iqro' bergantian dan mereka tidak bisa belajar sendiri di rumah karena tidak memiliki iqro', ${ }^{18}$

Adapun faktor penghambat dari ekstrakurikuler Azkiya' adalah personil pemain hadrah kurang, alat hadrah mudah rusak dan masih kurang, pelatih yang selama ini dari luar yaitu Bapak Khoiru Man digantikan oleh beberapa santri putri yang bisa. Karena pelatih dari dalam, maka menimbulkan kesan agak menyepelekan. Sehingga mereka latihan kurang konsisten. ${ }^{19}$ Keadaan ini akan menghambat peran ekstrakurikuler dalam meningkatkan nilai karakter santri, karena latihan mereka kurang maksimal, sehingga mereka tidak melatih diri untuk meningkatkan karakter mereka.

Faktor penghambat yang ada dalam ekstrakurikuler kaligrafi adalah motivasi santri yang kurang stabil atau masih tergantung mood dalam menghasilkan karya atau berlatih. Sehingga keberlangsungan ekstra ini terganggu, peran ekstra dalam meningkatkan karakter santri pun akan memudar. Kejadian ini hanya berlaku bagi anggota ekstra yang kurag aktif. Selain itu, belum adanya tempat khusus untuk menyalurkan bakat kaligrafi juga merupakan faktor penghambat. ${ }^{20}$

Adapun faktor penghambat dalam ekstra tilawah adalah kurangnya Sumber Daya Manusia (SDM) karena beberapa kru tilawah ada yang keluar pondok (boyong) dan belum ada pembukaan rekruitmen anggota baru. Akibatnya tenaga Lay Out di PPNU-Pi belu ada lagi. ${ }^{21}$ Kurangnya SDM merupakan penghambat terbesar, karena faktor inilah yang yang menentukan berjalan tidaknya suatu ekstrakurikuler.

Dari sini dapat diringkas bahwa faktor penghambat pelaksanaan ekstrakurikuler adalah sarana dan prasarana yang ada kurang mencukupi, kualitas sumber daya manusia (SDM) yang semakin

${ }^{18}$ Wawancara dengan saudari Dewi Asiyah Zulfa, anggota TBD. Pada tanggal 1 Mei 2013. Pukul 09.00 WIB.

${ }^{19}$ Wawancara dengan saudari Sodimah, anggota Azkiya'. Pada tanggal 1 Mei 2013. Pukul 08.00 WIB.

20 Wawancara dengan Ibu Zuni Afifah, pelatih kaligrfi. Pada tanggal 24 April 2013. Pukul 22.00 WIB.

21 Wawancara dengan saudari Dwi Rahmawati, kru tilawah. Pada tanggal 1 Mei 2013. Pukul 11.00 WIB. 
menurun dan semangat para santri dalam melakukan kegiatan kurang stabil.

\section{Kesimpulan}

Dari penjelasan di atas dapat diambil kesimpulan sebagai berikut:

1. Bentuk pelaksanaan ekstrakurikuler yang ada dalam PPNU-Pi untuk meningkatkan karakter santri itu dengan terselenggaranya ekstrakurikuler Tim Bina Desa (TBD) yang bergerak di bidang dakwah. Dilakukan oleh anggota TBD setiap hari Ahad secara bergantian sesuai jadwal yang berlokasi di Gunungkidul, Yogyakarta. Selanjutnya ekstrakurikuler hadrah (Azkiya) dilakukan setiap hari Sabtu atau Ahad di gedung PPNU-Pi. Untuk ekstrakurikuler kaligrafi, bertempat di Musala Darussalam, dilakukan setiap hari Jumat pukul 16.00-17.00 WIB. Sedangkan ekstrakurikuler tulis menulis (Tilawah), menerbiktan Koran Nurul Ummah (Korma), setiap tiga hari sekali dan majalah setiap enam bulan sekali. Pelaksanaan seluruh ekstrakurikuler sudah berjalan dengan baik, karena sudah terlaksana sebagaimana perencanaan yang ada.

2. Nilai-nilai karakter yang dapat ditingkatkan melalui ekstrakurikuler TBD adalah seluruh nilai karakter yang dirumuskan oleh Kemendiknas, mengingat kompleksnya objek ekstrakurikuler TBD dan luasnya ruang gerak yang ada. Nilai tersebut adalah nilai religius, jujur, toleransi, disiplin, kerja keras, kreatif, mandiri, demokratis, rasa ingin tahu, menghargai prestasi, komunikatif, cinta damai, gemar membaca, peduli lingkungan, peduli sosial, dan tanggung jawab. Dalam ekstrakurikuler Azkiya', tidak semua nilai karakter dapat ditingkatkan, dikarenakan ruang lingkup yang terbatas dalam anggota Aqkiya' saja. Nilai yang tidak dapat ditingkatkan adalah jujur, semangat nasionalisme, cinta tanah air, menghargai prestasi, gemar membaca, peduli lingkungan, dan peduli sosial. Hal ini hampir sama dengan yang terjadi dalam ekstrakurikuler kaligrafi. Ruang gerak mereka yang kurang luas dan bergelut dengan karya kaligrafi, sehingga tidak dapat memikirkan dan meningkatkan nilai-nilai kejujuran, cinta tanah air, menghargai prestasi, peduli lingkungan, dan peduli sosial. Sedangkan dalam ekstrakurikuler Tilawah, hampir semua nilai karakter dapat ditingkatkan. Mengingat objek ekstra yang luas, sehingga banyak nilai karakter yang dapat ditingkatkan. Hanya saja nilai menghargai prestasi satu-satunya nilai yang belum dapat ditingkatkan, karena 
realitanya memang belum adanya kegiatan pemberian penghargaan prestasi dalam ekstra ini.

3. Faktor pendukung pelaksanaan ekstrakurikuler adalah adanya semangat/motivasi, rasa ikhlas, kekompakan yang dimiliki santri yang mengikuti ekstrakurikuler dan dukungan yang diberikan oleh pihak luar baik pengurus, pengasuh maupun para alumni, serta tersedianya sarana dan prasarana yang ada. Sedangkan faktor penghambatnya adalah sarana dan prasarana yang ada kurang mencukupi, kualitas sumber daya manusia (SDM) yang semakin menurun dan semangat dalam melakukan kegiatan kurang stabil.

\section{DAFTAR PUSTAKA}

John Echols dan Hassan Shadily. Kamus Inggris Indonesia: An EngglishIndonesian Dictionary, Jakarta: PT Gramedia, 1995.

Kemendiknas, Pengembangan Karakter dan Budaya Bangsa, Jakarta:Puskur, 2010

Lexu J. Moloeng, Metodologi Penelitian Kualitatif, Bandung: Remaja Rosdakarya, 1993.

Mastuki dkk, Manajemen Pondok Pesantren. Jakarta: Diva Pustaka, 2005.

Moh Yamin, Menggugat Pendidikan Indonesia, Yogyakarta: Ar-Ruzz Media, 2009.

Robert Bogdan, Pengantar Metode Penelitian Kualitatif, Surabaya: Usaha Nasional, 1992.

Suharsimi Arikunto, Prosedur Penulisan: Suatu Pendekaan Praktek, Jakarta: Rineka Cipta Edisi Revisi IV, 1998.

Suryosubroto, Proses Belajar Mengajar di Sekolah, Jakarta: PT Rineka Cipta, 2002.

Tim Penyusun Kamus Pusat dan Pengembangan Bahasa, Kamus Besar Bahasa Indonesia, Jakarta: Balai Pustaka, 2005. 